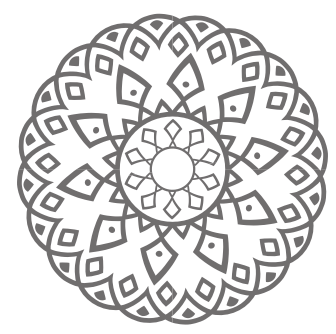

\title{
Mediation in The Religious Courts OF INDONESIA
}

\author{
Karmawan
}

\begin{abstract}
Abstrak: Kajian ini membahas efektifitas mediasi dalam kasus perdata di Pengadilan Agama di Indonesia. Dengan menggunakan pendekatan studi hukum normatif, artikel ini bertujuan untuk menganalisis implementasi PERMA No. 1/2006 tentang Mediasi di Pengadilan Agama. Mediasi diyakini dapat menjadi solusi untuk mengurangi jumlah kasus yang dibawa ke pengadilan, karena dengan mediasi berbagai sengketa hukum dapat diselesaikan tanpa litigasi. Kesepakatan yang dihasilkan dalam proses mediasi akan dicatat oleh mediator dan memiliki konsekuensi hukum yang sama dengan putusan hakim. Kajian ini menyimpulkan bahwa lembaga peradilan di Indonesia perlu berupaya secara serius untuk mengoptimalkan mediasi dan memberikan keadilan melalui mediasi.
\end{abstract}

Kata kunci: mediasi, Hukum Perdata Islam, Pengadilan Agama 
Abstract: This study discusses mediation in civil law cases in the Indonesian Religious Courts as a mean to solve the court congestion problem. This is a normative legal study and aims at analyzing the implementation of Supreme Court Regulation No. 1 of 2016 in the Religious Courts. In practice, agreements resulted from mediation will be ratified by a mediator and have similar legal consequences as judges'decisions. This, in turn, helps the court reducing the number of cases brought before the court. This study argues that the success of mediation relies on mediators' professionalism and legal culture in society. The success is also shown by the number of agreements issued as the result of mediation.

Keywords: mediation, Islamic civil law, Religious Courts 


\section{Introduction}

Law Number 30 of 1999 and Law Number 48 of 2009 explicitly determine mediation as one way to settle disputes outside the court. These laws and regulations are used as a legal basis for mediation. However, academics, practitioners and lawyers question the competence of the Religious Courts, where the mediation takes place. Alternative Dispute Resolution is the implementation of a settlement method to resolve disputes outside the court. The settlement methods include consultation, negotiation, mediation, conciliation, and expert judgment. A more in-depth examination of the implementation of mediation shows that the success of mediation generally rests on the willingness to bargain; deliberation to reach consensus; and prioritization of peaceful dispute resolution. The motivation of the parties to resolve a dispute is determined by their ability to bargain (bargaining position) against the disputed object.

Alternative Dispute Resolution is very relevant in efforts to develop genuine community participation. Global and national policy trends encourage community involvement in decision making (influence participation). With the involvement of the community in a decision-making process, it is necessary to create a forum to deal with conflicts that arise during the community involvement. The absence of conflict resolution mechanism will result in the ineffective implementation of community participation (Susanti Adi Nugroho 2019:60).

When mediation is taking place, the problem of case accumulation and case backlog in the judiciary will be resolved. Moreover, the role of disputants will be more significant than judges, who will become more passive and merely facilitate the mediation. If an agreement is reached through mediation, then the case will no longer need to be resolved at the court.

Since the enactment of the Supreme Court Regulation of the Republic of Indonesia Supreme Court Regulation No. 1 of 2016 concerning Procedures for Conducting Mediation at the Court Level, mediation has become one of the important agendas in the civil litigation proceeding both in General Courts and Religious Courts. Various parties have recommended that mediation become 
a critical process in the court before litigation. One way to enforce mediation before litigation in court is by the possible cancelation of a court decision that does not consider mediation. More clauses can also be determined to encourage disputant parties to intensify mediation.

Normatively, the mediation procedure should make judicial personnel, certified mediators and disputant parties understand the role of mediation. The Supreme Court Regulation No. of 2016 explains "that the parties are obliged to attend in person in a mediation meeting with or without a legal representative". In Indonesia, the mediation process is in line with the culture of Indonesian people who gave a deliberative nature in dealing with disputes. People can take more benefits from mediation compared to litigation. However, the fact still shows that people currently have not optimally used mediation and prefer litigation over mediation (Rahmawati 2016:8).

The mediator is central to the mediation process. Therefore, a mediator is required to know the problem before holding a mediation meeting. Moreover, a mediator should have patience in dealing with the parties, because the success of the mediation process requires the touch of a professional mediator, who plays his/her role and function well (Dorothy J. Della Noce 2008:198).

The implementation of mediation in Religious Courts is one of a political step (siyāsah syar'iyyah), as it becomes a mean of seeking the best public interests (maslahah). The Maliki school developed the concept of maslahah 'ammah or public interests. The notion of maslahah 'ammah is not only related to worship but also other matters such as human relationships. The maslahah 'ammah should be in harmony with the soul of shari'a and should not contradict one of the sources of sharia. Furthermore, the maslahah should be based on the essential matters and not tertiary ones (Azhari 1992:7). Umar Shihab divided the public interests into four criteria: 1) it aims at completing the objectives of the sharia: 2) its use must be simple and acceptable to reasons (logical); 2) it aims to overcome difficulties; 4) its use is for the public interest (Usman 2001:112).

The practice of mediation in the Religious Courts is still not optimal. This is because mediation can only be carried out under certain conditions determined by the Religious Courts. The result of 
mediation is similar to judges'decisions. Until currently, mediation has not become a legal culture of the community. Such a culture needs to be developed from the Religious Courts. Many cases taken to the mediation process have been successful, but some also unsuccessful. This failure is because some of the parties avoid mediation. Mediation can be used as the basis of case resolution justly and wisely. The data from the Supreme Court of the Republic Indonesia reveals that from the 25,318 cases brought to the court in $2013,148,241(17.8 \%)$ of them were successfully solved through mediation. In 2014, there were $24.7 \%$ of cases successfully solved through mediation or 132, 223 cases. In 2015, on the other hand, from 6.046 cases taken to mediation, there were only $1,019(16.85 \%)$ successful ones. Those percentages show that the community still has not used mediation effectively at the Religious Courts (IICT 2015).

\section{Discussion}

\section{Competence of Religious Courts in Mediation}

In the mediation process in the Religious Courts, mediators provide legal consideration for disputant parties to solve their problems fairly. Generally, a settlement through mediation in the Religious Courts is a responsive sense of justice developed among the community in the field of Islamic civil cases, which marriage, inheritance, child custody, and joint property cases. In this case, the legal substance and the level of public responsiveness of justice are related to the sociological development of contemporary Muslim society (Abdillah 2005:327).

The implementation of mediation in the Religious Courts for Islamic civil cases is regulated in Article 39 of Law No. 1 of 1974; Article 56 of Law Number 7 of 1989; the most recently amended by Law Number 50 of 2009; Articles 115, 131, 143 and 144 of the Compilation of Islamic Law; and Article 32 Government Regulation No. 9 of 1975. The provisions in those Articles require mediators to reconcile the parties in the mediation process. Peace efforts are not only carried out by a mediator at the beginning of a session but every session. Judges are required to always offer a reconciliation effort method in each trial process because the non-litigation legal settlement is far better compared to litigation. In civil cases, mediation, mediators are required 
to invite parties outside the disputants to provide more information. It is expected that the parties can reach a Settlement Agreement. If these efforts fail, then, the mediators proceed the case to the courts (Karmawan n.d.).

Mediation becomes crucial so that the parties can resolve their cases without proceeding to the next stage. If there are parties who are not pleased with the mediation process, they can resolve the case amicably or by means of deliberation. The purpose of mediation is to achieve peace among litigants who are usually trying to reach an agreement. Such difficulties can often be overcome by the presence of a third party, which in this case is a mediator. The mediator is to facilitate the parties by filtering information around the problem so that it becomes more apparent for the litigants. With this, they can be aware of the importance of reconciliation (Loveinheim 1999:2).

Mediating Islamic civil cases, however, requires mediators who are trusted by the community, and has the capacity to resolve those cases. The biggest problem with the implementation of mediation in the religious court is the emotional aspects of the parties. In other words, the success of mediation is seen from mediators'ability to deal with litigants and encourage them to take mediation into account (Brown 1985:81).

Mediation employs the principle of deliberation, which is the philosophy of the Indonesian people in the decision making process. This is mentioned in the fourth principle of Pancasila. It is stated that democracy is led by wisdom in consultation/representation. This high value is explained further in the 1945 Constitution and several laws and regulations. The principle of deliberation to reach consensus is the underlying value used by litigants to find solutions outside the court. The value of deliberation becomes an alternative form of dispute resolution such as mediation, arbitration, negotiation, facilitation, and various other forms of dispute resolution (S. Benton and B. Setiadi 1998).

In Indonesia, the principle of deliberation has been used in the legislation process. This can be seen from a number of laws and regulations since Indonesian independence, which contains the principle of peaceful deliberation as one of the principles of justice in Indonesia (Harahap 1997a:237-38). Now, this principle is also used in 
the Religious Courts, especially in dealing with Islamic civil disputes. Moreover, there is a call to strengthen the principle of reconciliation in mediation and arbitration. This is because case settlements often need a long time and result in winning and losing parties. This often complicates the relationship of the parties after the issuance of a judicial decision, and the parties are not free to pursue their dispute resolution options (Green 2002:291).

Mediation based on deliberation will end towards a peace agreement. Alternative dispute resolution in the rule of law is significant, considering Indonesia as a state of law (rechtsstaat) (Pringgodigdo 1981). In a state of the law, the actions of state institutions and state apparatus must have a legal basis because the actions of the state or state apparatus with no legal basis can be canceled or become null and void by law. Mediation as an institution for dispute resolution can be carried out by a judge as a state apparatus in court or other parties outside the court. Thus, its implementation requires the rule of law (Rahmah 2019).

Since the enactment of Law Number 1 of 1974 and Law Number 7 of 1989, there has been an increase in courts'power and authority. At the same time, the number of court units at the first instance and the appellate level also experienced rapid growth (Bisri 2000:166). The executive, judicial apparatus, namely judges and substitute executors, are prepared in terms of quality. The frequency and cases received, examined, tried, decided and resolved in the religious court environment increased significantly, especially during the last four years of the enactment of Law Number 1 of 1974 . Then, the cases gradually developed almost constantly. With the increase in the caseloads, there has been a need for additional personnel and facilities to carry out the courts' power and authority. The Religious Courts in Indonesia was established based on Law No. 7 of 1989. The Act complemented the provision of the Religious Courts mentioned in Law No. 14 of 1970 concerning the Basic Provisions of Judicial Power. Then, Law No. 7 of 1989 became an effort to develop and renew national law (Talib 2013:39-49).

Yahya Harahap (Harahap 1977:25) identified the main objectives of Law Number 7 of 1989. These are 1) to emphasize the position and power of Religious Courts as one of the implementations of 
judicial power in Indonesia; 2) to create a legal unit of Islamic justice; 3 ) to refine the function of Islamic justice. Before the promulgation of Law No. 7/1989, the authority of the Religious Courts was artificial and subordinated by the general court.(Lihat pasal 63 ayat (1) Undang-Undang Nomor 1 Tahun 1974 tentang Perkawinan n.d.) These objectives are based on various regulations governing the Religious Courts. There are at least 3 (three) provisions governing the composition, power and procedural law in the Religious Courts (Muhammad 2000:104).

In the enactment of Law Number 7 of 1989 (Anshori n.d.:27), the functions and structure of the power structure of the Religious Court are purely refined and enforced without interference from the general justice environment. Based on Law No. 7 of 1989, the authority of the Religious Courts is regulated in Article 49 paragraph (1). It says that the Religious Courts have the duty and authority to examine, decide upon, and settle cases at the first instance court for Muslims in the fields of (a) marriage; (b) inheritance, testament, and bequest carried out based on Islamic law; (c) waqf (endowment) and sadaqah (alms) which are regulated by the state laws (Karmawan n.d.).

As explained by the Supreme Court regulation, a mediator is obliged to help the parties to trace and explore the interests of the parties during the mediation process. The mediator must help the parties to express their interests and also to know the interests of the other party. In the end, common interests of both parties can be found, and the mediators can also help parties make sensible choices in their case resolution efforts to reach an agreement.

The obligation of mediators to reconcile the parties is in line with moral demands and teachings. Therefore, judges need to be aware of the function of reconciliation. Even in a fair decision, there will be winning and losing party. It is impossible to have all win or lose. The fairness of the decision given by the panel of judges will be deemed unfair by the losing party. However, even mistakes in decisions will be considered fair by the winning party. In mediation and reconciliation, the peace resulted from the process comes from the mutual awareness of the litigants. They are free from being the winner or loser because both of them are victorious. With this, both parties still can maintain their good relationship (Harahap 1977:47-48). 
Mediators bring together a different interest in order to reach the meeting point of the root of the problem. In this case, the mediator must be able to explore the problems, including the hidden ones. This stage is the verification stage to obtain unrevealed information. During this stage, the expertise of mediators to obtain information from both parties is needed. Thus, the mediator does not only act as an intermediary but also helps design the resolution method, which expected to results in a mutual agreement.

\section{Effectiveness of Mediation}

The implementation of mediation in the religious court is in accordance with the principle of a simple, fast, and low-cost court. Mediation is effective if the parties do not submit their cases to the court because they feel helped by the mediator who handles the case through mediation. Harrington and Marry (Harrington, Christine B dan Merry 1988:715), explained that mediation would promise convenience for each case. The mediators assist in a limited forum to the parties to resolve private problems and put forward the rationality of the law. Regarding the mediation in the Religious Courts in Indonesia, the level of effectiveness is seen from the simple technical implementation, in terms of cost and time spent for mediation until both parties reach an agreement and a mediation certificate is issued. Yahya Harahap explains that the meaning and purpose of the principle of simple, fast, and low-cost judicial process is the examination process that relatively fast, which does not take years, and in accordance with the simplicity of procedural law (Harahap 1977).

The principle of simple, fast, and low-cost justice is regulated by Law No. 7 of 1989, Article 57 paragraph (3). This principle is rooted in the provisions of Article 4 paragraph (2) of law No 14 of 1970. The broader meaning of this principle is explained in the general explanation and explanation of Article 4 paragraph (2), which states "justice is carried out in simple, fast, and low-cost manners, but it must be adhered that is reflected in the laws on criminal procedural law and civil procedural law, which contain much simpler inspection and verification regulations."

Furthermore, the purpose and meaning of the principle of justice are further emphasized in the explanation of Article 4 paragraph (2) 
which states "The court must fulfill the expectations of justice seekers who always want a judiciary that is fast, accurate, fair, and low in cost." There is no need for investigations and troublesome affairs that can lead to a more protracted process of trial, which may take years. In this case, the parties must continue to seek justice in the Religious Courts. When the parties seek justice, a mediator may also find difficulties to carry out mediation if one party or both put forward emotions. As a consequence, a solution may be hard to be found. If the parties hold their emotions and respect the mediation process, then the mediation process can be easier, and the case can be solved at a low cost. Low cost means that both parties spend less to solve their dispute.

In terms of fulfilling a sense of justice, justice-seekers can achieve it without having to go to the court, which may take a long time, and high costs. The mediation meeting becomes a strategic effort to develop a mutual understanding to achieve a peace agreement. The meeting conducted by the mediator can be very efficient in terms of time and cost. The meeting should take place in the Religious Courts. Taking place outside the court may lead to difficulties for the parties. The meeting can be held between four to six times. In general, the meeting will result in an agreement between the parties, and the issuance of the final result of mediation.

\section{The Strength of the Settlement Agreement}

With mediation implemented in the Religious Courts, disputes can be settled peacefully (Salim 2008:92). It is also expected that the disputes are resolved timely without hostility between the parties. If fact, not all mediation process runs as expected. However, when the mediation process is successful, and the outcome of the agreement is reached, a Settlement Agreement becomes the evidence that disputant parties agree to make peace (Subekti 1995:177). The process of reaching an agreement by both parties is a stage that must be carried out by the mediator. The role of a mediator to reconcile the parties is more important than filing a case to the court. In this case, the court has the power to give decisions on the settlement agreement made by the parties before the mediator when the peace agreement occurs. 
A Settlement Agreement is made when both parties have reached an agreement in mediation. This Settlement Agreement then issued in the form of a court decision. It can be concluded that the Settlement Agreement aims to put the case to an end or to prevent the emergence of a new case. The agreement should be formalized; otherwise, it is not legitimate and unbinding. The formal requirement to be met by all parties is that they have to agree to end the ongoing disputes voluntarily. This agreement should purely come from the involving parties (Subekti 1995:178).

A Settlement Agreement will have a legal binding after it issued in the form of a court decision. To become a Settlement Agreement, the agreement reached in the mediation must be decided by a panel of judges, as explained earlier. If the agreement has not yet become a Settlement Agreement, then the agreement is weak. This is because the agreement is made only by the involving parties without any supervision of a competent authority. In other words, if one day, a problem occurred regarding the contents of the agreement, the mediator does not immediately respond to this. The parties, in this case, need to bring their case back to the court. This is different when a court decision issues the agreement. It will have a similar status as common judge decisions, which is final and have legal binding (Rahmadi 2010:76-78).

A peace agreement or a settlement agreement is requested for legalization by a panel of judges. A peace agreement is similar to other ordinary agreement, which is limited only to the parties. This is because the agreement has not undergone legalization through a decision of the panel of judges. Consequently, when a problem comes up, the case is re-submitted to the court as a new case, and cannot be directly executed. The function of a Settlement Agreement is as evidence of peace agreement and a proof that the agreement is valid and binding. As a result, when a problem comes up, the Religious Courts through the court clerk or bailiff led by a judge can directly execute the contents of the Settlement Agreement. This is done to consider the value of humanity and justice (M. Fauzan 2007:9).

The principle of deliberation and peace is reflected in the civil procedural law in the court. For example, the parties must seek peace through a mediation process and the decision-making process in the 
court. However, there is still a question of whether deliberation and peace between a plaintiff and defendant exist in a procedural legal process. If the question is related to the concept of the Indonesian rule of law, such as kinship, harmony, and balance, of course, the deliberation and peace are not in conflict with the ideals of the Indonesian rule of law. In addition, there is also a question related to the relationship between the principle of presumtio justea causa or the principle of het vermoeden van rechtmatigheid. This principle is possible if it is associated with a dispute or objection or appeal from the party affected or feels disadvantaged by the decision. However, if the parties in the litigation are aware of their mistakes, the case does not need to be continued. The case is resolved by deliberation so that peace and agreement are achieved (Islam 1945).

\section{Legal Culture in Mediation}

Efforts to bring about justice or settle cases in court through mediation by the parties are not a new tradition for the Indonesian people. This is proven by Article $130 \mathrm{HIR}$ and Article $154 \mathrm{RBg}$ made by the Dutch East Indies government, applied to the indigenous (pribumi) group. That Article requires legal cases to be tried in the court before judges. The judges are obliged to reconcile the parties. However, in its development, the settlement efforts in civil cases have been merely a formality, or to merely fulfill the norms of civil procedural law.

For the mediation process to be optimally implemented in case resolution, the involving parties need to understand the purpose and objectives of the mediation. Thus, the parties can be convinced that the court will conduct a trial in transparent, efficient, and effective manners in accordance with justice. Therefore, efforts to optimize mediation in civil procedural proceedings need to encourage settlement efforts through mediation in court. In addition, there is a need to increase legal awareness by promoting mediation in Religious Courts (Karmawan n.d.).

It is common knowledge; the accumulation of cases in Indonesian justice institutions continues. This accumulation is due to the notion to resolve a case in a win-win solution has not become a culture in the community (Rahmawati 2016:7). As a result of the case congestion, the 
handling time for a legal case taken to court often needs to take years until it reaches a permanent legal decision (Harahap 1997b:237). Thus, the process can be a waste of energy, time, and cost for the litigants. This condition has not discouraged the litigants from continuing trusting the judiciary to settle their cases (Sulistiyono 2013).

Indonesian society has a value of deliberations in every discussion and dispute resolution in the community. However, it seems that people have lost their appreciation for the practice and value of deliberation. This can be seen in the violence that often takes place in dealing with disputes. Therefore, mediation can be a solution to the redevelop the culture of deliberation in order to resolve dispute faster and with low cost, as well as to avoid hostility between the involving parties.

In the modern legal system, the judiciary has a task to resolve every case emerged in society. It is the duty of the judiciary to uphold the rule of law and provide access to justice to the people. It is proven in its development that in settlement of legal cases in the courts, justice seekers often meet an excessive formality, inefficiency, ineffectiveness, high costs, corruption, and disappointing or injustice legal decisions.

It is further explained that the settlement of legal cases in courts often leads to dissatisfaction of the parties as well as the community. Public dissatisfaction towards judiciary is expressed in the form of cynical views, ridiculing, and even blaspheming the performance of the judiciary. The settlement efforts outside the court must be accepted. The reason is that the use of litigation as a means to seek justice often faces structural obstacles. The main obstacle in the modern justice system is caused by the excessive emphasize of formality, procedures, bureaucracy, and strict method. Thus, justice in modern society is nothing but rational bureaucratic justice (Suparman 2012:117).

In order to develop trusts in the community to mediation, there is a need to make mediation a part of the community cultural value. Besides, the people should believe that mediation is in accordance with the value of community in dispute settlement. Therefore, the formal education system from elementary school to tertiary level needs to introduce the importance of mediation and communicate the noble values of consensus in society. Efforts to increase public legal awareness can be more effective and efficient through education. This 
is because education is not an incidental act, but it a continuous and intensive activity. It would not be an exaggeration to say that through an intensive discussion about mediation in the education process, the results of the efforts to enhance and foster legal awareness through education can be seen in at least the next 18 or 19 years. After that, the mediation process in court can be well implemented. This is not something to be faced with pessimism. This must be welcomed with unanimous determination to succeed (William S. Haft 1998:214).

Thus, the efforts of the parties to seek justice through alternative means outside the judiciary is an effort to reduce obstacles. Marc Galanter (1985) explains that justice can be obtained from several institutions, not just from justice institutions. He further explained that there are two different processes in settlement of cases, namely negotiation and litigation. The integration between the two is called litigotiation (Galanter 1985:1). This process mobilizes the judiciary by putting forward the principle of negotiations in reaching an agreement. Agreement through negotiation is needed to reduce the accumulation of cases in the court, and also reduce the number of human resources needed in the court (Galanter n.d.). In addition, the implementation of negotiations during mediation is not only carried out through forums provided by the state, but also by the broader community by utilizing the location of primary activities, such as homes, workplaces, and others. Thus, the implementation of negotiations in mediation is flexible, more friendly, and removes the formality and bureaucratic barriers.

Friedman (Suparman 2012) explains that to build a legal culture related to mediation, three components need to work together, namely structure, substance, and culture. The legal system has a structure that is the framework of a permanent legal system in order to be maintained at its limits, especially those relating to its jurisdiction. The substance is the norm, and human resources are in the system. Culture is a legal culture that is the human attitude towards the legal system. This legal culture determines how legal instruments are used and or misused. Thus, the implementation of mediation will work well in a community if these three important components work together and strengthen one another. In other languages, Friedman (1986) further tries to link legal and non-legal in any change in society. Non-legal is related to 
the legal culture that grows and develops in people's lives. If the legal product produced as an important instrument in the legal system, then the smooth implementation of mediation in the court will become the legal culture of the community in settling cases against litigants (Friedman 1986:763).

In practice, the ideals or ideas of legal certainty, justice, and benefits are almost impossible to be achieved in a balanced way. Legal certainty is one of the supporting directions for law enforcement. Then, the other supporting direction, namely justice and expediency, will be reduced, even vice versa. The emphasis on one aspect of either certainty of justice is strongly influenced by the legal traditions adopted by the community. A country that adheres to the Civil Law tradition, which is based on law and legislation, will lead to legal certainty.

In comparison, countries that adhere to the tradition of the Common Law tradition that is based on custom and case law, the sense of justice of the community is more accommodated through judge-made law. In addition to the certainty and justice aspects, in law enforcement, consideration must also be given to the usefulness aspects of community law. This is not because the law is implemented or enforced. Instead, anxiety arises in the community. The law is for the community and not the community for the law (Ismayawati 2011:60). Building a legal culture becomes very important because a good legal culture will produce a good legal system, as explained earlier that the legal culture is very influential on the existence of the legal substance and legal structure. No matter how good the substance of the law if a good legal culture of society does not support it, then the legal substance is only a collection of writings about the rules that are not meaningful.

\section{Conclusions}

As a conclusion of this study reveals that the benchmarks of the effectiveness of mediation settlement of Islamic civil cases are viewed from several aspects. First, the implementation of mediation relies on mediators'professionalism in carrying out the mediation process. Mediators are required to have patience and know the problems well in order to explore the problems with the parties. This knowledge can be 
used in the mediation process. The mediation process becomes efficient in terms of time and cost spent if the parties agree to make peace. Second, the effectiveness is seen based on how many Settlement Agreements issued as a result of mediation. This is because the case resolved no longer needs to proceed through a trial. The issuance of a Settlement Agreement reflects the good faith of disputant parties. Third, the legal culture of the community needs to optimize the culture of mediation in court further. In addition, increasing public legal awareness by promoting mediation in the Religious Courts is in accordance with the culture of the Indonesian people, which prioritizes deliberation in decision making in the community. Wallahu a'lam bishowaab.

\section{References}

Abdillah, Masykuri dkk. (2005). Formalisasi Syariat Islam Di Indonesia Sebagai Sebuah Pergulatan Yang Tak Pernah Tuntas. Jakarta: Renaisan.

Anshori, Abdul Ghofur. n.d. Peradilan Agama Di Indonesia Pasca Undang-Undang Nomor 3 Tahun 2006: Sejarah, Kedududkan, Dan Kewenangan.

Azhari, Muhammad Tahir. (1992). Negara Hukum Suatu Studi Tentang PrinsipPrinsipnya Dilihat Dari Segi Hukum Islam, Implementasinya Pada Periode Negara Madinah Dan Masa Kini. Jakarta: Bulan Bintang.

Bisri, Cik Hasan. (2000). Peradilan Islam Dalam Tatanan Masyarakat Indonesia. Bandung: PT. Remaja Rosdakarya,.

Brown, Emily M. (1985). Emotional Dynamics or Couples in Mediation. Dalam James C Hansen, and Grebe, Sarah Childs. Journal Divorce and Family Mediation 81.

Dorothy J. Della Noce, et all. (2008). Singosys And Crossroads: A Model For Live Action Mediator Assesment. Ohio State Journal on Dispute Resolution 23:198.

Friedman, Lawrence M.(1986). The Law and Society Movement. Stanford Law Review, 38(3):763.

Galanter, Marc. (1985). ... A Settlement Judge, Not a Trial Judge:'Judicial Mediation in the United States. Journal of Law and Society 12(1):1.

Galanter, Marc. n.d.... A Settlement Judge, Not a Trial Judge: Judicial Mediation in the United States.

Green, Stephen B. (2002). Arbitrase: A Viable Alternative for Solving Commercial Disputes in Indonesia, Dalam Timothy Lindsey (Ed.).

Harahap, M. Yahya. (1977). Kedudukan Kewenangan Dan Acara Peradilan Agama: Undang-Undang Nomor 7 Tahun 1989.

Harahap, M. Yahya. (1997a). Beberapa Tinjauan Mengenai Sistem Peradilan Dan Penyelesaian Sengketa. Bandung: Citra Aditya Bakti. 
Harahap, M. Yahya. (1997b). Beberapa Tinjauan Mengenai Sistem Peradilan Dan Penyelesaian Sengketa. Bandung: PT. Citra Aditya Bakti.

Harrington, Christine B dan Merry, Sally Engle. (1988). Idoelogical Production: The Making of Community Mediation.Jurnal Law San Society Review 22(4):715.

IICT. (2015). Monitoring on the Implementation of Court-Annexed Mediation Pilot Project. Jakarta.

Karmawan Universitas Islam Negeri Syarif Hidayatullah Jakarta Karmawan @ Unis . Ac . Id 3(1):251-67.

Ismayawati, Any. (2011). Pengaruh Budaya Hukum Terhadap Pembangunan Hukum Di Indonesia ( Kritik Terhadap Lemahnya Budaya Hukum Di Lndonesia ). Pranata Hukum 6 No.1.

Karmawan. (n.d.) "Mediasi Merupakan Bentuk Penyelesaian Sengketa Di Luar Pengadilan Yang Dewasa Ini Digunakan Pengadilan Sebagai Proses Penyelesaian Sengketa . Pengintegrasian Mediasi Ke Dalam Proses Beracara Di Pengadilan Memiliki Potensi Sebagai Sarana Untuk Menyelesaika." (10):107-26.

Loveinheim. (1999). Negoisasi Dan Mediasi. Jakarta: Elips.

M. Fauzan. (2007). Pokok-Pokok Hukum Acara Peradilan Agama Dan Mahkamah Syariyyah Di Indonesia. Jakarta: Kencana.

Muhammad, Abdul Kadir. (2000). Hukum Perdata Indonesia. Bandung: Citra Aditya.

Perdata Islam (1945).

Pringgodigdo. (1981). Tiga Undang-Undang Dasar. Jakarta: PT Pembangunan.

Rahmadi, Takdir. (2010). Mediasi: Penyelesaian Sengketa Melalui Pendekatan Mufakat. Jakarta: Raja Grafindo Persada.

Rahmah, Dian Maris. (2019). Optimalisasi Penyelesaian Sengketa Melalui Mediasi di Pengadilan. Jurnal Bina Mulia Hukum 4(42):1-16.

Rahmawati, Erik Sabti. (2016). Implikasi Mediasi Bagi Para Pihak Yang Berperkara Di Pengadilan Agama Malang. Journal de Jure 8(1):1.

S. Benton and B. Setiadi. (1998). Mediation and Conflict Management in Indonesia, in Conflict Management in the Asia Pacific: Assumption and Approaches in Diverse Cultures, Ed. L. Kwok and D. Tjosvold. Singapore: John Wiley \& Sons.

Salim. (2008). Hukum Kontrak: Teori Dan Teknik Penyusunan. Jakarta: Sinar Grafika.

Subekti. (1995). Aneka Perjanjian. Bandung: PT. Citra Aditya Bakti.

Sulistiyono, Adi. (2013). Merasionalkan Budaya Musyawarah Untuk Mengembangkan Penggunaan Penyelesaian Sengketa Win-Win Solution. In Orasi Ilmiah Dalam Rangka Dies Natalis XXIX Universitas Sebelas Maret Disampaikan Pada Sidang Senat Terbuka Universitas Sebelas Maret Tanggal 12 Maret. Jakarta. 
Suparman, Eman. (2012). Arbitrase Dan Dilema Penegakan Keadilan. Jakarta: PT Fikahati Aneska bekerjasama dengan Badan Arbitrase Nasiolnal Indonesia.

Susanti Adi Nugroho. (2019). Manfaat Mediasi Sebagai Alternatif Penyelesaian Sengketa,. Jakarta: Prenada Media.

Talib, Idris. (2013). Bentuk Putusan Penyelesaian Sengketa Berdasarkan Mediasi. Lex et Societatis I(1):39-49.

Undang-Undang Nomor 1 Tahun 1974 tentang Perkawinan. n.d. "No Title."

Usman, Suparman. (2001). Hukum Islam: Asas-Asas Dan Pengantar Studi Hukum Islam Dalam Tata Hukum Indonesia. Jakarta: Gaya Media Pratama.

William S. Haft, Elaine R. Weiss. (1998). Peer Mediation In Schools: Expectations and Evaluations. Harvard Negotiations Law Review 3:214. 